\title{
Effectiveness of Fiscal and Financial Incentive Mechanism in Promoting the Development of TCM Health Industry
}

\author{
Zhixuan Huang ${ }^{1, \mathrm{a}}$, Jun $\mathrm{Li}^{2, \mathrm{~b} *}$ (Corresponding author) \\ ${ }^{1}$ Hubei University of Chinese medicine Wuhan, Hubei, China \\ ${ }^{2}$ Hubei University of Chinese medicine Wuhan, Hubei, China
}

\begin{abstract}
On the basis of field research, this paper uses AHP and fuzzy comprehensive evaluation method to study the effectiveness of financial incentive mechanism in promoting the development of Chinese medicine health industry. The results show that the effectiveness of financial incentive mechanism in Chinese medicine health industry is not enough. The government should strengthen the construction of financial incentive mechanism in Chinese medicine health industry and pay attention to the regulation of relevant policies It is necessary to set up and implement the plan, so as to realize the modernization of the health industry of traditional Chinese medicine as soon as possible.
\end{abstract}

\section{Introduction}

At present, the epidemic situation in China tends to be stable, and the role of traditional Chinese medicine in the epidemic has made people pay more and more attention to it. Therefore, the great health market of traditional Chinese medicine has more prospects for development. According to the data from the National Bureau of Statistics, the proportion of medical and health care consumption in per capita consumption expenditure has been growing steadily year by year. With the increase of market demand, the development prospect of the big health industry is getting better and better, among which the proportion of TCM in the big health industry has been growing continuously. From 2011 to 2017, the market scale of Chinese medicine big health industry continued to rise. In 2017, it has reached 1750 billion yuan, a year-on-year increase of $21.1 \%$. [1] According to the white paper "China's traditional Chinese medicine" issued by the Information Office of the State Council, in 2020, China's traditional Chinese medicine big health industry has exceeded 3 trillion, with an average annual compound growth rate of $20 \%$.It can be seen that China's TCM industry has a strong potential for development in the future. Traditional Chinese medicine industry is a characteristic industry in China. In this paper, questionnaire survey, expert interview, interview survey and other methods are used to collect and sort out the data of various aspects of Chinese medicine health industry financial policy. SPSS software and excel are used for statistical analysis of the data. At the same time, AHP and fuzzy comprehensive analysis are used to analyze and summarize the effectiveness of Chinese medicine health industry financial policy.

\section{Empirical analysis}

Health industry is to maintain, improve and promote the health as the goal, to improve people's physical and mental health and subjective feeling for the service standards, provide all health related products and services of a set of production activities, production and service is closely related to human health, a long industrial chain, with wider coverage . [2]Health industry is an emerging industry with huge market potential, the famous American economist Paul pilzer in wave $\mathrm{v}$ of the wealth, health industry is called the global after IT industry "the fifth wave of wealth". At present, for the health industry, the TCM health industry is the organic combination of TCM and the big health industry. TCM health services mainly include health preservation, health care, medical treatment, rehabilitation, etc., but the core of which is the health service supply mainly based on TCM related products. In recent years, the government increased the policy support to industry of Chinese medicine, and with the national industrial structure adjustment and enterprise, the combination between the derived a series of beauty beauty makeup, health care and other traditional Chinese medicine of traditional Chinese medicine of traditional Chinese medicine health industry: with medical service institutions as the main body of the medical industry of traditional Chinese medicine; Traditional Chinese medicine industry with the production and sale of drugs, medical devices and other medical consumables as the main body; TCM health care products industry with health food and health products as the main body; Traditional Chinese medicine health service industry with health consultation service, health pension, health 
tourism, sports and fitness, conditioning and rehabilitation and insurance as the main body.

Motivation theory is a summary of principles and methods about how to meet people's various needs and arouse people's enthusiasm. At present, motivation theory includes four types: content theory, process theory, reinforcement theory and comprehensive theory.[3]

Incentive mechanism is a rational system to reflect the way of interaction between the incentive subject and the incentive object, that is, the use of certain methods and management system to maximize the interaction between the incentive subject and the object, to achieve the goal. Incentive mechanism mainly includes the following aspects: Inductive factor set, Behavior oriented system, Range of behavior system, Conduct domestication system, Behavioral space-time system.[4]

\section{Analysis of the effectiveness of financial policy incentive mechanism}

\subsection{Selection of indicators}

According to the indicators of the government and universities, the indicators are divided into three levels and summarized into the table as shown in Table 1:

Table1 Evaluation index system for effectiveness of financial policies and measures in TCM health industry

\begin{tabular}{|c|c|c|c|c|c|}
\hline \multicolumn{2}{|c|}{ Level 1 indicators } & \multicolumn{2}{|l|}{$\begin{array}{l}\text { Secondary } \\
\text { indicators }\end{array}$} & \multicolumn{2}{|l|}{ Three levels of indicators } \\
\hline \multirow{9}{*}{$\begin{array}{l}\text { Gover } \\
\text { nment }\end{array}$} & \multirow{9}{*}{ A1 } & \multirow{3}{*}{$\begin{array}{l}\text { The content } \\
\text { of the } \\
\text { policy }\end{array}$} & \multirow{3}{*}{ B1 } & $\begin{array}{l}\text { The content is comprehensive and } \\
\text { complete }\end{array}$ & $\mathrm{C} 1$ \\
\hline & & & & Targeted & $\mathrm{C} 2$ \\
\hline & & & & Government support & $\mathrm{C} 3$ \\
\hline & & \multirow{3}{*}{$\begin{array}{l}\text { The } \\
\text { implementa } \\
\text { tion of the } \\
\text { policy }\end{array}$} & \multirow{3}{*}{ B2 } & Awareness of policies and initiatives & $\mathrm{C} 4$ \\
\hline & & & & Satisfaction with policies and initiatives & $\mathrm{C} 5$ \\
\hline & & & & $\begin{array}{l}\text { The degree to which policies and } \\
\text { initiatives are implemented }\end{array}$ & C6 \\
\hline & & \multirow{3}{*}{$\begin{array}{l}\text { The } \\
\text { benefits of } \\
\text { the policy }\end{array}$} & \multirow{3}{*}{ B3 } & $\begin{array}{l}\text { Develop the characteristic industries of } \\
\text { Chinese medicine }\end{array}$ & $\mathrm{C} 7$ \\
\hline & & & & $\begin{array}{l}\text { Improve the economic benefits of the } \\
\text { Chinese medicine health industry }\end{array}$ & $\mathrm{C} 8$ \\
\hline & & & & $\begin{array}{l}\text { To promote the development of the } \\
\text { "Chinese medicineand "industry }\end{array}$ & C9 \\
\hline \multirow[b]{2}{*}{$\begin{array}{l}\text { Univer } \\
\text { sity }\end{array}$} & \multirow[t]{2}{*}{ A2 } & \multirow[b]{2}{*}{$\begin{array}{l}\text { The } \\
\text { effectivenes } \\
\text { s of the } \\
\text { policy }\end{array}$} & \multirow[b]{2}{*}{ B4 } & $\begin{array}{l}\text { Strengthen the training of Chinese } \\
\text { medicine talents }\end{array}$ & $\mathrm{C} 10$ \\
\hline & & & & $\begin{array}{l}\text { We will promote the independent } \\
\text { innovation and technology of Chinese } \\
\text { medicine }\end{array}$ & $\mathrm{C} 11$ \\
\hline
\end{tabular}




\subsection{Analytic Hierarchy Process (AHP)}

Analytic Hierarchy Process (AHP) is a pairwise comparison of the importance of each index through expert scoring to form an objective and reasonable pairwise comparison matrix. The steps are as follows:

(1).Scale determination and construction of judgment matrices

Assuming that there are $\mathrm{m}$ evaluation indicators, this article refers to the number 1-9 and its inverse as a scale, as detailed in Table2, and is judged by the expertscore on the matrix $S=(S$ ij $) m \times m$.

Table2 determines the matrix scale and its meaning

\begin{tabular}{|l|l|}
\hline Scale & Meaning \\
\hline 1 & $\begin{array}{l}\text { The two indicators are of the same } \\
\text { importance as each other }\end{array}$ \\
\hline 3 & $\begin{array}{l}\text { The former is slightly more important than } \\
\text { the latter compared to the two indicators }\end{array}$ \\
\hline 5 & $\begin{array}{l}\text { The former is more important than the latter } \\
\text { compared to the two indicators }\end{array}$ \\
\hline 7 & $\begin{array}{l}\text { The former is more important than the latter } \\
\text { compared to the two indicators }\end{array}$ \\
\hline 9 & $\begin{array}{l}\text { The former is more important than the latter } \\
\text { compared to the two indicators }\end{array}$ \\
$6,4 、$ & $\begin{array}{l}\text { The scale value between the two } \\
\text { comparisons above }\end{array}$ \\
\hline $\begin{array}{l}\text { Coun } \\
\text { tdow } \\
\mathrm{n}\end{array}$ & $\begin{array}{l}\text { If the ratio of the importance of indicator } \mathrm{i} \\
\text { and } \mathrm{j} \text { is } \mathrm{s}, \text { the ratio of the importance of } \\
\text { indicator } \mathrm{j} \text { to indicator } \mathrm{i} \text { is } 1 / \mathrm{s}\end{array}$ \\
\hline
\end{tabular}

(2).First-level indicator weight calculation and consistency test

Calculate the weight Wi and consistency metrics

Calculate the maximum eigenvalue Max and the corresponding eigenvector according to the judgment matrix, and normalize to get the weight vector $\mathrm{Wi}=$ (W1,W2,W3).

Calculate the consistency metric CI:

$$
\mathrm{CI}=\frac{\lambda_{\max }-\mathrm{m}}{\mathrm{m}-1}
$$

Table 3 RandomLy Consistent RI Values

\begin{tabular}{|l|l|l|l|l|l|l|l|l|l|}
\hline nth-order & 1 & 2 & 3 & 4 & 5 & 6 & 7 & 8 & 9 \\
\hline RI value & 0 & 0 & 0.52 & 0.89 & 1.12 & 1.26 & 1.36 & 1.41 & 1.46 \\
\hline
\end{tabular}

Calculate the consistency ratio:

$$
\mathrm{CR}=\frac{\mathrm{CI}}{\mathrm{RI}}
$$

In general, the smaller the $\mathrm{Cr}$ value is, the better the consistency of the judgment matrix is. In general, if the $\mathrm{Cr}$ value is less than 0.1 , the judgment matrix meets the consistency test. If the $\mathrm{Cr}$ value is greater than 0.1 , then there is no consistency Results:

The first-level indicators and their consistency test results are shown in the table below:
Table4 level 1 indicators and their consistency test results

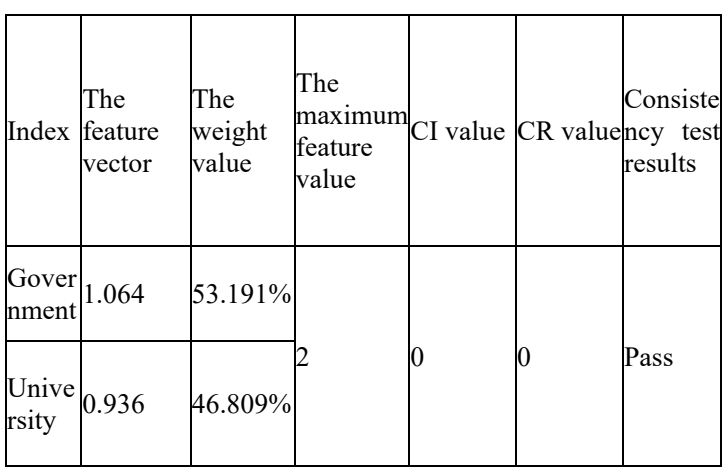

(3).Secondary index weight calculation and consistency test

The weightof the secondary indicator iscalculated according to the repeated steps above, and the results are as follows:

Table5 secondary indicators and their consistency test results

\begin{tabular}{|l|l|l|l|l|l|l|}
\hline item & $\begin{array}{l}\text { The } \\
\text { feature } \\
\text { vector }\end{array}$ & $\begin{array}{l}\text { The weight } \\
\text { value }\end{array}$ & $\begin{array}{l}\text { The } \\
\text { maximum } \\
\text { feature value }\end{array}$ & $\begin{array}{l}\text { CI } \\
\text { value }\end{array}$ & $\begin{array}{l}\text { CR } \\
\text { value }\end{array}$ & $\begin{array}{l}\text { Consistency } \\
\text { test results }\end{array}$ \\
\hline B1 & 0.744 & $16.378 \%$ & & & & \\
B2 & 0.457 & $29.726 \%$ & & & \\
B3 & 1.073 & $53.896 \%$ & 4.202 & 0.067 & 0.076 & Pass \\
\hline B4 & 1.726 & $46.809 \%$ & & & & \\
\hline
\end{tabular}

(2) Multiply the first-level metric weight with the above weight value to get the final weight as follows:

Table 6 Final Weight Value of Secondary Indicators

\begin{tabular}{|l|l|l|l|}
\hline B1 & B2 & B3 & B4 \\
\hline $8.712 \%$ & $15.812 \%$ & $28.668 \%$ & $46.809 \%$ \\
\hline
\end{tabular}

(4).Weight calculation and consistency test of three-level indicators

According to the above steps, the weights of the three-level indicators were calculated again and the consistency test was carried out. The results showed that all the three-level indicators passed the consistency test. The weight values are shown in the following table:

Table7 Three-level indicator weight values

\begin{tabular}{|l|l|l|l|}
\hline Index & $\begin{array}{l}\text { The weight } \\
\text { value }\end{array}$ & Index & $\begin{array}{l}\text { The weight } \\
\text { value }\end{array}$ \\
\hline C1 & $24.711 \%$ & C7 & $16.378 \%$ \\
\hline C2 & $28.977 \%$ & C 8 & $53.896 \%$ \\
\hline C3 & $46.311 \%$ & C9 & $29.726 \%$ \\
\hline C4 & $16.378 \%$ & C10 & $71.429 \%$ \\
\hline C5 & $29.726 \%$ & C11 & $28.571 \%$ \\
\hline C6 & $53.896 \%$ & & \\
\hline
\end{tabular}

Multiply the second-level metric weight with the above weight value to get the final weight as follows: 
Table 8 Final weight value of the three-tier indicator

\begin{tabular}{|l|l|l|l|}
\hline Index & $\begin{array}{l}\text { The final } \\
\text { weight } \\
\text { value }\end{array}$ & Index & $\begin{array}{l}\text { The final } \\
\text { weight value }\end{array}$ \\
\hline C1 & $2.153 \%$ & C7 & $4.695 \%$ \\
\hline C2 & $2.524 \%$ & C 8 & $15.451 \%$ \\
\hline
\end{tabular}

\begin{tabular}{|l|l|l|l|}
\hline C3 & $4.035 \%$ & C9 & $8.521 \%$ \\
\hline C4 & $2.590 \%$ & C10 & $33.435 \%$ \\
\hline C5 & $4.700 \%$ & C11 & $13.374 \%$ \\
\hline C6 & $8.522 \%$ & & \\
\hline
\end{tabular}

In summary, all indicators and their weighting values are shown in the table below:

Table9 All indicator weight values

\begin{tabular}{|c|c|c|c|c|c|}
\hline \multicolumn{2}{|c|}{$\begin{array}{ll}\text { Level } & 1 \\
\text { indicators } & \end{array}$} & \multicolumn{2}{|c|}{ Secondary indicators } & \multicolumn{2}{|l|}{ Three levels of indicators } \\
\hline \multirow{9}{*}{$\begin{array}{l}\text { Gove } \\
\text { rnme } \\
\text { nt }\end{array}$} & \multirow{9}{*}{$\begin{array}{l}53.1 \\
91 \%\end{array}$} & \multirow{3}{*}{$\begin{array}{l}\text { The content } \\
\text { of the policy }\end{array}$} & \multirow{3}{*}{$8.712 \%$} & $\begin{array}{l}\text { The content is comprehensive } \\
\text { and complete }\end{array}$ & $2.153 \%$ \\
\hline & & & & Targeted & $2.524 \%$ \\
\hline & & & & Government support & $4.035 \%$ \\
\hline & & \multirow{3}{*}{$\begin{array}{l}\text { The } \\
\text { implementati } \\
\text { on of the } \\
\text { policy }\end{array}$} & \multirow{3}{*}{$15.812 \%$} & $\begin{array}{l}\text { Awareness of policies and } \\
\text { initiatives }\end{array}$ & $2.590 \%$ \\
\hline & & & & $\begin{array}{l}\text { Satisfaction with policies and } \\
\text { initiatives }\end{array}$ & $4.700 \%$ \\
\hline & & & & $\begin{array}{l}\text { The degree to which policies } \\
\text { and initiatives are implemented }\end{array}$ & $8.522 \%$ \\
\hline & & \multirow{3}{*}{$\begin{array}{l}\text { The benefits } \\
\text { of the policy }\end{array}$} & \multirow{3}{*}{$28.668 \%$} & $\begin{array}{l}\text { Develop the characteristic } \\
\text { industries of Chinese medicine }\end{array}$ & $4.695 \%$ \\
\hline & & & & $\begin{array}{l}\text { Improve the economic benefits } \\
\text { of the Chinese medicine health } \\
\text { industry }\end{array}$ & $15.451 \%$ \\
\hline & & & & $\begin{array}{l}\text { To promote the development of } \\
\text { the "Chinese medicineand " } \\
\text { industry }\end{array}$ & $8.521 \%$ \\
\hline \multirow[b]{2}{*}{$\begin{array}{l}\text { Univ } \\
\text { ersity }\end{array}$} & \multirow[b]{2}{*}{$\begin{array}{l}46.8 \\
09 \%\end{array}$} & \multirow[b]{2}{*}{$\begin{array}{l}\text { The } \\
\text { effectiveness } \\
\text { of the policy }\end{array}$} & \multirow[b]{2}{*}{$46.809 \%$} & $\begin{array}{l}\text { Strengthen the training of } \\
\text { Chinese medicine talents }\end{array}$ & $33.435 \%$ \\
\hline & & & & $\begin{array}{l}\text { We will promote the } \\
\text { independent innovation and } \\
\text { technology of Chinese } \\
\text { medicine }\end{array}$ & $13.374 \%$ \\
\hline
\end{tabular}

\subsection{Score the effectiveness of fiscal and financial policy based on fuzzy comprehensive evaluation method}

Questionnaire survey was adopted in this paper. A total of 314 electronic questionnaires were sent out by Questionnaire Star and 314 were collected with 100\% recovery rate and $100 \%$ effective rate. The questionnaires were collected from 18 provinces in
China.

\subsubsection{Survey content}

The questionnaire adopts the Richter Scale of five levels, through the evaluation of the indicators of each three levels, the evaluation content is "best, better, average, poor, worst". The overall situation is shown in the following table: 
Table10 Fill in the three levels of evaluation

\begin{tabular}{|c|c|c|c|c|c|}
\hline Index & Worst & Poor & average & Better & Best \\
\hline $\begin{array}{l}\text { The content is } \\
\text { comprehensive and } \\
\text { complete }\end{array}$ & 1 & 4 & 92 & 165 & 52 \\
\hline Targeted & 3 & 8 & 93 & 119 & 91 \\
\hline Government support & 4 & 5 & 72 & 162 & 71 \\
\hline $\begin{array}{l}\text { Awareness of policies } \\
\text { and initiatives }\end{array}$ & 6 & 17 & 102 & 127 & 62 \\
\hline $\begin{array}{lr}\begin{array}{l}\text { Satisfaction } \\
\text { policies } \\
\text { initiatives }\end{array} & \text { with } \\
\end{array}$ & 3 & 10 & 88 & 142 & 71 \\
\hline $\begin{array}{l}\text { The degree to which } \\
\text { policies } \\
\text { initiatives and } \\
\text { implemented }\end{array}$ & 5 & 11 & 106 & 123 & 69 \\
\hline $\begin{array}{l}\text { Develop the } \\
\text { characteristic } \\
\text { industries of Chinese } \\
\text { medicine }\end{array}$ & 3 & 6 & 66 & 150 & 89 \\
\hline $\begin{array}{l}\text { Improve the } \\
\text { economic benefits of } \\
\text { the Chinese medicine } \\
\text { health industry }\end{array}$ & 2 & 8 & 78 & 135 & 91 \\
\hline $\begin{array}{l}\text { To promote the } \\
\text { development of the } \\
\text { "Chinese } \\
\text { medicineand } \\
\text { industry }\end{array}$ & 2 & 5 & 69 & 128 & 110 \\
\hline $\begin{array}{l}\text { Strengthen the } \\
\text { training of Chinese } \\
\text { medicine talents }\end{array}$ & 1 & 4 & 56 & 150 & 103 \\
\hline $\begin{array}{l}\text { We will promote the } \\
\text { independent } \\
\text { innovation and } \\
\text { technology of } \\
\text { Chinese medicine }\end{array}$ & 1 & 4 & 69 & 132 & 108 \\
\hline
\end{tabular}

According to the above model, the five ratings of evaluation are best, better, average, poor, worst, and the quantitative score is $100,80,60,40,30$.

According to the number of each evaluation grade, the fuzzy membership degree of each three indexes can be obtained. If the unqualified number of $\mathrm{C} 1$ (full and complete) is $2,1 / 314=0.0032$ (4 decimal places are reserved). By analogy, the general table of fuzzy membership can be obtained, as shown in Table11.

Table11 Three-level indicators Fuzzy membership

\begin{tabular}{|l|l|l|l|l|l|}
\hline Index & Worst & Poor & average & Better & Best \\
\hline $\begin{array}{l}\text { The content is } \\
\text { comprehensive } \\
\text { and complete }\end{array}$ & 0.0032 & 0.0127 & 0.2930 & 0.5255 & 0.1656 \\
\hline Targeted & 0.0096 & 0.0255 & 0.2962 & 0.3790 & 0.2898 \\
\hline $\begin{array}{l}\text { Government } \\
\text { support }\end{array}$ & 0.0127 & 0.0159 & 0.2293 & 0.5159 & 0.2261 \\
\hline $\begin{array}{l}\text { Awareness of } \\
\text { policies and } \\
\text { initiatives }\end{array}$ & 0.0191 & 0.0541 & 0.3248 & 0.4045 & 0.1975 \\
\hline $\begin{array}{l}\text { Satisfaction with } \\
\text { policies and } \\
\text { initiatives }\end{array}$ & 0.0096 & 0.0318 & 0.2803 & 0.4522 & 0.2261 \\
\hline $\begin{array}{l}\text { The degree to } \\
\text { which policies } \\
\text { and initiatives } \\
\text { are implemented }\end{array}$ & 0.0159 & 0.0350 & 0.3376 & 0.3917 & 0.2197 \\
\hline Develop the & 0.0096 & 0.0191 & 0.2102 & 0.4777 & 0.2834 \\
\hline
\end{tabular}




\begin{tabular}{|l|l|l|l|l|l|}
\hline $\begin{array}{l}\text { characteristic } \\
\text { industries of } \\
\text { Chinese } \\
\text { medicine }\end{array}$ & & & & & \\
\hline $\begin{array}{l}\text { Improve the } \\
\text { economic } \\
\text { benefits of the } \\
\text { Chinese } \\
\text { medicine health } \\
\text { industry }\end{array}$ & 0.0064 & 0.0255 & 0.2484 & 0.4299 & 0.2898 \\
\hline $\begin{array}{l}\text { To promote the } \\
\text { development of } \\
\text { the "Chinese } \\
\text { medicineand " } \\
\text { industry }\end{array}$ & 0.0064 & 0.0159 & 0.2197 & 0.4076 & 0.3503 \\
\hline $\begin{array}{l}\text { Strengthen the } \\
\text { training of } \\
\text { Chinese } \\
\text { medicine talents }\end{array}$ & 0.0032 & 0.0127 & 0.1783 & 0.4777 & 0.3280 \\
\hline $\begin{array}{l}\text { We will promote } \\
\text { the independent } \\
\text { innovation and } \\
\text { technology of } \\
\text { Chinese } \\
\text { medicine }\end{array}$ & 0.0032 & 0.0127 & 0.2197 & 0.4204 & 0.3439 \\
\hline
\end{tabular}

The evaluation matrix of each three-level indicator is obtained, and the rating evaluation assignment vector $\mathrm{D}=$ $(30,40,60,80,100)$ is multiplied by the evaluation matrix of $\mathrm{C} 1 \sim \mathrm{C} 11$ respectively to obtain the scores of each three-level indicator as shown in Table12:

Table 12 Scores for each of the three levels of indicators

\begin{tabular}{|l|l|l|l|l|l|l|l|l|l|l|l|}
\hline Index & C1 & C2 & C3 & C4 & C5 & C6 & C7 & C8 & C9 & C10 & C11 \\
\hline Score & 76.78 & 78.38 & 78.66 & 74.33 & 77.17 & 75.45 & 80.22 & 79.49 & 81.66 & 82.32 & 81.82 \\
\hline
\end{tabular}

The secondary indicators are then scored.

According to the above method, each secondary indicator evaluation matrix can be selected as :

Table 13 Judgement Matrix of Secondary Indicators

\begin{tabular}{|l|l|l|l|l|l|}
\hline $\begin{array}{l}\text { Inde } \\
\mathrm{x}\end{array}$ & Worst & Poor & $\begin{array}{l}\text { averag } \\
\mathrm{e}\end{array}$ & Better & Best \\
\hline B1 & 0.0085 & 0.0180 & 0.2728 & 0.4735 & 0.2272 \\
\hline B2 & 0.0149 & 0.0403 & 0.3142 & 0.4161 & 0.2144 \\
\hline B3 & 0.0074 & 0.0202 & 0.2261 & 0.4384 & 0.3079 \\
\hline B4 & 0.0032 & 0.0127 & 0.1990 & 0.4490 & 0.3360 \\
\hline
\end{tabular}

Each secondary indicator can be scored as:

Table 14 Scores for secondary indicators

\begin{tabular}{|l|l|l|l|l|}
\hline Index & B1 & B2 & B3 & B4 \\
\hline Score & 77.94 & 75.64 & 80.46 & 82.06 \\
\hline
\end{tabular}

Repeat the steps to get a first-level indicator evaluation matrix:

Table 15 Judgement Matrix of Level 1 Indicators

\begin{tabular}{|l|l|l|l|l|l|}
\hline $\begin{array}{l}\text { Inde } \\
\mathrm{x}\end{array}$ & Worst & Poor & average & Better & Best \\
\hline A1 & 0.0103 & 0.0262 & 0.2711 & 0.4427 & 0.2498 \\
\hline A2 & 0.0032 & 0.0127 & 0.1990 & 0.4490 & 0.3360 \\
\hline
\end{tabular}

The first-level indicator score can be:

Table 16 Scores for level-one indicators

\begin{tabular}{|l|l|l|}
\hline Index & A1 & A2 \\
\hline Score & 78.01 & 82.06 \\
\hline
\end{tabular}

The final total score is 80.04 .

\section{Problems explained}

\subsection{Fiscal and financial incentives are not well targeted}

Although the Chinese government has a set of mechanisms to stimulate the development of TCM health industry, the content of fiscal and financial incentive policies still needs to be improved. At present, most fiscal and financial policies appear as a part of the policies to promote the development of the health industry of traditional Chinese medicine, rather than independently. Therefore, the pertinence of the contents of fiscal and financial policies needs to be strengthened.Moreover, from the perspective of the income ratio, the income of TCM medical institutions continues to increase in the total income of medical institutions, but it still accounts for less than $10 \%$. At present, the income of TCM medical institutions still 
lags behind that of general hospitals. It is necessary to increase the proportion of income in the total income of medical institutions by expanding the scale and improving the management and operation ability, which also needs the support of fiscal and financial policies.And whether the follow-up industry can increase economic benefits and develop smoothly is also closely related to whether the policy can "apply the medicine to the case". Traditional Chinese medicine health industry market needs more perfect industry standards and industry self-discipline.

\subsection{Policy advocacy is insufficient}

The insufficient publicity of fiscal and financial incentive policies will lead to the lack of motivation for the implementation of follow-up policies. The publicity intensity of the policy affects people's awareness of the content of the policy, and only when the content of the policy is understood can the follow-up implementation take place. Only $15.29 \%$ of the respondents were familiar with the policy. At present, the awareness of fiscal and financial incentive policies is not enough, and many people are unfamiliar with the content of the policies, which is also caused by the insufficient publicity of the policies. The degree of policy implementation is based on the degree of policy publicity. To effectively implement the policy, increasing the degree of policy publicity is the key.

\subsection{Insufficient government support}

Government support is the core force that all policies can be effectively implemented. Government support is the guarantee of policy implementation, and policies with strong support can be carried out effectively during implementation. On the other hand, there are obstacles to execution. Government support is supported by a sound policy system, complete related supporting policies and high government attention to policies. The government pays more attention to the application of fiscal and financial policies in the field of TCM health industry, but the relevant supporting policies are not complete and the policy system is not perfect. Therefore, the government's financial incentive policies to promote the development of TCM health industry support is not enough.

\subsection{The results of scientific and technological transformation and personnel training are weak}

One of the biggest problems in the development of TCM health industry is weak product research and development. The core of industrial development lies in innovation, creating something that others do not have is the key to improve the core competitiveness. Although China has issued relevant policies to encourage the transformation of scientific and technological achievements, but little effect; Despite the rapid development of traditional Chinese medicine industry in recent years, the attraction of western medicine is still greater than that of traditional Chinese medicine, and it is difficult for colleges and universities of traditional Chinese medicine to attract talents, which directly affects the effectiveness of talent training.In order to accelerate the transformation process of scientific and technological achievements and personnel training, it is necessary to have the effective guidance of government funds and strong financial support, but so far, this aspect is still lacking.

\section{Countermeasures and suggestions to improve the fiscal and financial incentive mechanism}

\subsection{Improve the financial and financial incentive policy mechanism and improve the policy content}

Finance is a system of distribution "controlled by the government and the executive through financing". The fiscal and financial policies of TCM health industry in China should take national development strategy as the goal. At the same time, the concept of public finance should be continued, the implementation of government functions should be detailed, and policies should be implemented. Fiscal and financial policies are important tools to support the development of TCM health industry. We will establish a stable financial investment guarantee mechanism for TCM, and strive to build a diversified investment system for TCM that is guided by government investment, dominated by investment from enterprises, supported by financial investment and participated by private investment. Only by improving the policy content and providing targeted financial assistance to the TCM health industry can we achieve the effect of "medicine to cure diseases". [5]

\subsection{Increase publicity efforts to promote the development of Chinese medicine health industry}

The reason why the fiscal and financial policies fail to achieve the expected effect of the country is that the object of the policy does not understand the content of the policy, which must be due to the insufficient publicity of the policy content. Only by understanding the content of the policy can we further implement the policy and develop the TCM health industry. After the contents of fiscal and financial policies are published, relevant departments should intensify their publicity and promotion efforts. Only when the object of the policy knows the contents of the policy can they be encouraged to develop the TCM health industry.

\subsection{Strengthen support and enhance the implementation of policies}

Government support is the guarantee of policy implementation. Only when policies with strong support are implemented can they be carried out effectively. To 
strengthen the government's support for fiscal and financial policies, it is necessary to establish a sound fiscal and financial policy system and introduce relevant policies to support the implementation of fiscal and financial policies. At the same time, it is necessary to pay close attention to the progress of policies and timely check and fill in the gaps. Only when the implementation of the policy is enhanced, will people have the will to develop innovation and entrepreneurship in the field of TCM health industry, thus promoting the development of TCM health industry.

\subsection{Strengthen the association of schools and enterprises to promote the transformation of results and personnel training}

The development of TCM health industry needs diversified talents. TCM colleges and universities should adjust and optimize the professional structure, reform the teaching content, and cultivate innovative and entrepreneurial talents with "benevolence, knowledge and ability" in the trinity of TCM industry based on skill renewal. It is necessary to strengthen the joint cooperation between universities, research institutes and enterprises. According to the market demand, enterprises should put forward the research and development direction and make use of the scientific and technological advantages of universities and research institutes to create new products with high-tech content, which can be directly put into production with enterprises and promote the timely transformation of achievements.Strengthen the degree of cooperation between hospitals and schools, reform the medical education system, and gradually build four levels of coordination mechanism between the government and the market, education system and health system, medical colleges and affiliated hospitals, units and society, so as to cultivate high-quality talents to promote the development of Chinese medicine. By using the properties of venture capital and the transformation of scientific and technological achievements, give play to the role of venture capital to promote the transformation of scientific and technological achievements, improve the multi-level capital market, fully meet the high-tech enterprises and small and medium-sized technology-based enterprises in different life cycle, capital requirements of different business areas, provide enterprises with direct financing, provide financial support to social transformation of scientific and technological achievements.

\section{Conclusions and prospects}

Nowadays, more and more attention is paid to the TCM industry, and the TCM health industry is a sunrise industry in the TCM industry, and the development of the TCM health industry is very important. Based on medical health industry fiscal and monetary policy are analyzed, and through the empirical study method (analytic hierarchy process (AHP), questionnaire investigation, etc.) to the policy effectiveness evaluation index system, the research analyzed financial incentive policies in people's minds and fiscal and monetary policies to promote the effectiveness of traditional Chinese medicine health industry development. Through research and analysis, this paper summarizes some problems existing in national policies and university initiatives, and analyzes some measures and suggestions to solve the problems. Of course, if we want to establish a sound fiscal and financial incentive mechanism, the government alone is not enough. We need the joint efforts of all parties. The development of TCM health industry is a new driving force for the development of TCM industry in China and an important direction for the development of TCM health industry in China.

\section{Acknowledgments}

Supported by the scientific research fund of traditional Chinese medicine of Hubei Provincial Health Commission "Research on the development policy of Chinese medicine health industry based on Incentive Theory" (Project No. ZY2021Q041)

\section{Resources}

1. Li Huan, Zhang Urbanbin, International Health Industry Development Path Study, Health Economics Research, March 38, 2021 Volume 3, No. 3, No. 407

2. Paul Pierze. The fifth wave of wealth. Beijing : China Social Science Press,2011.

3. Zhang Boli, Zhang Junhua,etc., Opportunities and Strategic Thinking for the Development of the Great Health Industry of Chinese Medicine, China Engineering Science 2017 Volume 19, No. 2

4. Ma Jinge Wei Rongrui -- An Analysisof the Innovative Development Model of The Great Health Industry of Chinese Medicine in the New Era,Science and TechnologyPlaza, No. 1 of 2018: 1671-4792 (2018) 01-37-06

5. Deepen the side supply reform -- promote the development of the chinese medicine health industry, Zhang Yuxuan, Du Lihong, Li Jun,2018 Hebei Province Social Science Development Research Topic "Hebei Province Chinese Medicine Health Industry Development Research." 